
\title{
25 Research Square \\ Urban Population Exposure to Air Pollution in Europe Over the Last Decades
}

Pierre Sicard ( $\square$ psicard@argans.eu )

ARGANS https://orcid.org/0000-0002-3136-7062

\section{Evgenios Agathokleous}

Nanjing University

Alessandra De Marco

enea

\section{Elena Paoletti}

IRET-CNR

Vicent Calatayud

CEAM

\section{Research}

Keywords: Air pollution, EU-28, Mann-Kendall test, Population exposure, Risk assessment, Trend

Posted Date: November 5th, 2020

DOl: https://doi.org/10.21203/rs.3.rs-101275/v1

License: (c) (1) This work is licensed under a Creative Commons Attribution 4.0 International License.

Read Full License

Version of Record: A version of this preprint was published on March 7th, 2021. See the published version at https://doi.org/10.1186/s12302-020-00450-2. 


\section{Abstract}

Background - The paper presents an overview of air quality in the 27 member countries of the European Union (EU) and the United Kingdom (previous EU-28), from 2000 to 2017. We reviewed the progress made towards meeting the air quality standards established by the EU Ambient Air Quality Directives (Directive 2008/50/EC) and the World Health Organization (WHO) Air Quality Guidelines by estimating the trends (Mann-Kendal test) in national emissions of main air pollutants, urban population exposure to air pollution, and in mortality related to exposure to ambient fine particles $\left(\mathrm{PM}_{2.5}\right)$ and tropospheric ozone $\left(\mathrm{O}_{3}\right)$.

Results - Despite significant reductions of emissions (e.g. sulfur oxides: $~ 80 \%$, nitrogen oxides: $\sim 46 \%$, non-methane volatile organic compounds: $\sim 4 \%$, particulate matters with a diameter lower than $2.5 \mu \mathrm{m}$ and 10 $\mu \mathrm{m}: ~ 30 \%$ ), the EU-28 urban population was exposed to $\mathrm{PM}_{2.5}$ and $\mathrm{O}_{3}$ levels widely exceeding the WHO limit values for the protection of human health. Between 2000 and 2017, the annual PM $2.5^{\text {-related }}$ number of deaths decreased (- 4.85 per $10^{6}$ inhabitants) in line with a reduction of $\mathrm{PM}_{2.5}$ levels observed at urban air quality monitoring stations. The rising $\mathrm{O}_{3}$ levels became a major public health issue in the EU-28 cities where the annual $\mathrm{O}_{3}$-related number of premature deaths increased $\left(+0.55\right.$ deaths per $10^{6}$ inhabitants).

Conclusions - To achieve the objectives of the Ambient Air Quality Directives and mitigate air pollution impacts, actions need to be urgently taken at all governance levels. In this context, greening and renaturing cities can help meet air quality standards, but also answer to social needs, as recently highlighted by the COVID-19 lockdowns.

\section{Background}

Outdoor air pollution is a major global public health issue (Lelieveld et al., 2015), leading to 4.2 million premature deaths worldwide (WHO, 2016) and half a million in the European Union (EU) in 2016 (EEA, 2018). The EU identifies seven main air pollutants (Koolen and Rothenberg, 2019): ammonia $\left(\mathrm{NH}_{3}\right)$, nitrogen oxides $\left(\mathrm{NO}_{\mathrm{x}}\right)$, carbon monoxide (CO), particulate matter with an aerodynamic diameter lower than $2.5 \mu \mathrm{m}$ and $10 \mu \mathrm{m}\left(\mathrm{PM}_{2.5}\right.$ and $\left.\mathrm{PM}_{10}\right)$, sulfur oxides $\left(\mathrm{SO}_{\mathrm{x}}\right)$, tropospheric ozone $\left(\mathrm{O}_{3}\right)$, and non-methane volatile organic compounds (NMVOCs). In cities, where $74 \%$ of the EU population lives (EU, 2016), $\mathrm{PM}_{2.5}$ and ground-level $\mathrm{O}_{3}$ have potentially the most significant effects on human health associated with respiratory and cardiovascular diseases and mortality, compared to other air pollutants (Pascal et al., 2013; WHO, 2013; Cohen et al., 2017). In 2016, 374,000 and 14,600 non-accidental premature deaths were attributed to air pollution $\left(\mathrm{PM}_{2.5}\right.$ and $\mathrm{O}_{3}$, respectively) in the EU-28 ${ }^{1}$ countries (EEA, 2018). Air pollution also damages plant ecosystems (Mills et al., 2011; Sicard et al., 2016a; Feng et al., 2019), and surface $\mathrm{O}_{3}$ is considered as the most detrimental air pollutant in terms of effects on vegetation and biodiversity (Paoletti, 2007; Sicard et al., 2016a; Agathokleous et al., 2020). 
The legislated ambient air quality standards and the emission control policies (e.g. European Council Directive 1996/62/EC; World Health Organization Air Quality Guidelines, WHO-AQG 2006; European Council Directive 2008/50/EC; National Emission Ceilings Directive, 2016; Convention on Long-range Transboundary Air Pollution, CLRTAP 2017) control emissions of harmful substances into the atmosphere, and regulate the concentrations of air pollutants such as $\mathrm{PM}_{2.5}, \mathrm{PM}_{10}, \mathrm{NO}_{2}$ and $\mathrm{O}_{3}$, by setting limit and target values for the protection of human health (Table 1). The Clean Air Programme for Europe (CAPE), published by the European Commission in 2013, aims to improve air quality in Europe by 2030 and to reduce the number of premature deaths by half compared with 2005 (EC, 2013). Following the above directives, the number of air quality monitoring stations grew rapidly in Europe with databases gathering air quality data such as the European Environment Agency Airbase system. Due to the spatial representativeness of monitoring stations and the duration of time series, the above database offers an unprecedented way for trends analysis, and peer-reviewed articles. 
Table 1

- Examples of air quality standards for common air pollutants as given in the European Ambient Air Quality Directive (Directive 2008/50/EC) and World Health Organization Air Quality Guidelines (WHO $A Q G)$ for the protection of human health.

\begin{tabular}{|c|c|c|}
\hline $\begin{array}{l}\text { Air } \\
\text { pollutant }\end{array}$ & $\begin{array}{l}\text { EU limit and target value } \\
\text { (threshold in } \mu \mathrm{g} \mathrm{m}^{-3} \text { ) }\end{array}$ & $\begin{array}{l}\text { WHO AQG } \\
\text { (threshold in } \mu \mathrm{g} \mathrm{m}^{-3} \text { ) }\end{array}$ \\
\hline${ }^{\mathrm{a}} \mathrm{PM}_{10}$ & Annual mean (40) & Annual mean (20) \\
\hline${ }^{\mathrm{a}} \mathrm{PM}_{10}$ & $\mathrm{Nb}$ of exceedance of $24-\mathrm{h}$ mean (50) & $\mathrm{Nb}$ of exceedance of 24-h mean (50) \\
\hline${ }^{\mathrm{b}} \mathrm{PM}_{2.5}$ & Annual mean (25) & Annual mean (10) \\
\hline${ }^{\mathrm{b}} \mathrm{PM}_{2.5}$ & - & $\mathrm{Nb}$ of exceedance of 24-h mean (25) \\
\hline${ }^{\mathrm{c}} \mathrm{O}_{3}$ & $\begin{array}{l}\mathrm{Nb} \text { of exceedance of maximum daily 8-h } \\
\text { mean (120) }\end{array}$ & $\begin{array}{l}\mathrm{Nb} \text { of exceedance of maximum daily 8-h } \\
\text { mean (100) }\end{array}$ \\
\hline${ }^{\mathrm{d}} \mathrm{NO}_{2}$ & Annual mean (40) & Annual mean (40) \\
\hline${ }^{\mathrm{d}} \mathrm{NO}_{2}$ & $\mathrm{Nb}$ of exceedance of $1-\mathrm{h}$ mean (200) & $\mathrm{Nb}$ of exceedance of 1 -h mean (200) \\
\hline${ }^{\mathrm{e}} \mathrm{SO}_{2}$ & $\mathrm{Nb}$ of exceedance of 24-h mean (125) & $\mathrm{Nb}$ of exceedance of 24-h mean (20) \\
\hline${ }^{\mathrm{f}} \mathrm{CO}$ & Maximum daily 8-h $(10,000)$ & Maximum daily 8-h $(10,000)$ \\
\hline
\end{tabular}

a Annual mean $\mathrm{PM}_{10}$ concentration and number of days with 24-hour $\mathrm{PM}_{10}$ concentration over $50 \mu \mathrm{g}$ $\mathrm{m}^{-3}$ for the protection of human health. The annual mean $\mathrm{PM}_{10}$ concentration does not to exceed $40 \mathrm{\mu g} \mathrm{m}^{-3}$ (Directive 2008/50/EC) or $20 \mathrm{\mu g} \mathrm{m}^{-3}$ (WHO AQG). The 24-h PM 10 mean concentration does not to exceed $50 \mathrm{\mu g} \mathrm{m}^{-3}$ (WHO AQG) or more than 35 times a year (EC). ${ }^{\mathrm{b}}$ Annual mean $\mathrm{PM}_{2.5}$ concentration and numbers of days with 24-h $\mathrm{PM}_{2.5}$ mean concentration over $25 \mu^{-g^{-3}}$ (WHO AQG). The annual mean $\mathrm{PM}_{2.5}$ concentration does not to exceed $25 \mu \mathrm{g} \mathrm{m}^{-3}$ (EC) or $10 \mu \mathrm{g} \mathrm{m}^{-3}$ (WHO AQG). ${ }^{c}$ For the protection of human health, the Directive 2008/50/EC has introduced a threshold of $120 \mu \mathrm{g}$ $\mathrm{m}^{-3}$ for the daily maximum 8-h average. The threshold level should not be exceeded on more than 25 times a year. Number of days with daily maximum 8-h $\mathrm{O}_{3}$ concentrations over $100 \mu \mathrm{g} \mathrm{m}^{-3}$ as limit value for the protection of human health (WHO AQG). ${ }^{d}$ Annual mean $\mathrm{NO}_{2}$ concentration and number of hours with $\mathrm{NO}_{2}$ concentrations above $200 \mu \mathrm{g} \mathrm{m}^{-3}$. The annual mean $\mathrm{NO}_{2}$ concentration does not to exceed $40 \mu^{-3} \mathrm{~m}^{-3}$ (EC and WHO AQG) while the hourly threshold should not be exceeded more than 18 times a year (EC). ${ }^{e}$ The $24-\mathrm{h} \mathrm{SO}_{2}$ mean concentration does not to exceed $125 \mu \mathrm{g} \mathrm{m}^{-3}$ more than 3 times a year (EC) and does not to exceed $20 \mu \mathrm{g} \mathrm{m}^{-3}$ (WHO AQG). ${ }^{\mathrm{f}}$ The Directives have introduced a threshold of $10 \mathrm{mg} \mathrm{m}^{-3}$ for the maximum daily 8-hour mean concentration. 
For the first time, through an extensive literature review and trends analysis, this study aims to i) quantify the annual trends in national emissions of main air pollutants in the EU-28 countries over the time period 2000-2017, ii) analyze the trends in real-world air pollutants concentrations over the last two decades; iii) assess the effectiveness of emissions control policies for reducing the exposure of EU-28 population to ambient air pollution, and iv) evaluate the impact of control policies on the number of premature deaths attributed to exposure to ambient $\mathrm{PM}_{2.5}$ and $\mathrm{O}_{3}$ levels over time.

${ }^{1}$ Including the United Kingdom, which withdrew from the European Union on $31^{\text {st }}$ January 2020.

\section{Materials And Methods}

\section{Data collection}

The national emissions of main air pollutants $\left(\mathrm{SO}_{x}, \mathrm{NH}_{3}, \mathrm{PM}_{2.5}, \mathrm{PM}_{10}\right)$ and main $\mathrm{O}_{3}$ precursors $\left(\mathrm{NO}_{\mathrm{x}}\right.$, NMVOCs, CO), officially submitted by the Parties to the LRTAP Convention, were obtained by the European Monitoring and Evaluation (EMEP) Program² ${ }^{2}$ The population exposure was estimated by the European Environmental Agency (EEA) from measured concentrations at urban and suburban background (non-traffic) monitoring stations across the EU-28 countries, with more than $75 \%$ of validated hourly data per year and station, and considering that the entire population is potentially exposed to the averaged concentrations (EEA, 2007; 2011-2019). The number of premature deaths attributed to exposure to ambient $\mathrm{PM}_{2.5}$ and $\mathrm{O}_{3}$ (per $10^{6}$ inhabitants) were obtained by the Organization for Economic Co-operation and Development ${ }^{3}$ (OECD). The above datasets were obtained over the time period 20002017.

\section{Estimation of the national number of premature deaths}

The number of non-accidental premature deaths attributable to ambient $\mathrm{PM}_{2.5}$ and $\mathrm{O}_{3}$ were estimated for each EU member country and year by the method described in detail in Global Burden of Diseases (GDB, 2018) and widely used for the health risk assessment of air pollution (Goudarzi et al. 2017; Amoatey et al., 2019a,b; Khaniabadi et al., 2018a,b, 2019; De Marco et al. 2018; Sicard et al., 2019).

WHO set daily maximum 8-hour concentrations for $\mathrm{O}_{3}$ and 24-hour average concentration for $\mathrm{PM}_{2.5}$ as metrics to represent the mean daily exposure of population (WHO, 2008). The population exposure to $\mathrm{O}_{3}$ and $\mathrm{PM}_{2.5}$ is estimated by combining satellite data, a chemical transport model, land use information, and finally calibrated by using ground measurements (GBD, 2018). For a health endpoint, the number of cases $N C_{c}$ attributed to the exposure to the air pollutant $c$ is calculated as $N C_{c}=B I \times A P$ where $B I$ is the baseline incidence rates and AP the attributable proportion, i.e. the fraction of a health endpoint that can be related to the exposure to $c$ in a population $P_{c}$ where RR is the relative risk value, i.e. the probability of developing a disease associated to an increase of $10 \mu \mathrm{g} \mathrm{m}^{-3}$ of the air pollutant $c$ concentration (WHO, 2018). 


$$
\mathrm{AP}=\frac{\sum\left[\left(R R_{c}-1\right) \times P_{c}\right]}{\sum\left[R R_{c} \times P_{c}\right]}
$$

These RR values are obtained from exposure-response functions, based on epidemiological studies, and published by WHO (2013). For the mortality "non-accidental causes", RR $=1.015$ and RR $=1.003$ are reported for $\mathrm{PM}_{2.5}$ and $\mathrm{O}_{3}$, respectively, i.e. for instance, a $10 \mu \mathrm{g} \mathrm{m}^{-3}$ increase in the 24-hour average $\mathrm{PM}_{2.5}$ concentration is associated with a $1.5 \%$ increase in the risk for mortality attributed to nonaccidental causes.

\section{Statistical estimation of annual trends}

A 10-year time-series is considered long enough to assess short-term changes (Sicard et al., 2009). The non-parametric Mann-Kendall test and the non-parametric Sen's slope estimator were used to detect changes within time-series and estimate the magnitude of trends (Sicard et al., 2013; Guerreiro et al., 2014). Both tests were applied for annual national emissions of main air pollutants and the number of premature deaths attributed to exposure to ambient $\mathrm{PM}_{2.5}$ and $\mathrm{O}_{3}$ levels in EU-28 countries over the time period 2000-2017. Results were considered significant at $p<0.05$.

\section{Literature review}

To report robust short-term air pollutants changes over the last two decades, approximately 50 peerreviewed articles and technical report spanning over the time period 2000-2017 were retrieved from literature databases (Science Direct, Web of Science, and Google scholar). We selected the studies with: i) in-situ observations from air quality monitoring networks (excluding modeled data); ii) annual mean concentrations; iii) at least 10 -year time-series of data; iv) more than $75 \%$ of data coverage annually; and v) significant trend, i.e. with a p-value $<0.05$.

${ }^{2}$ https://www.ceip.at

${ }^{3}$ https://stats.oecd.org

\section{Results And Discussion}

\section{Trends in national emissions}

Significant reductions were observed for the emission of all primary pollutants, i.e. $-4.7 \%$ year $^{-1}$ for $\mathrm{SO}_{\mathrm{x}}$ $-2.7 \%$ year $^{-1}$ for $\mathrm{NO}_{\mathrm{x}},-2.6 \%$ year $^{-1}$ for NMVOCs, $-0.6 \%$ year $^{-1}$ for $\mathrm{NH}_{3},-2.9 \%$ year ${ }^{-1}$ for $\mathrm{CO}$ and $-1.8 \%$ year ${ }^{-1}$ and $-1.7 \%$ year $^{-1}$ for $\mathrm{PM}_{2.5}$ and $\mathrm{PM}_{10}$, respectively, over the time period $2000-2017$ in the EU-28 (Table 2). The $\mathrm{SO}_{\mathrm{x}}$ emissions decreased in all EU-28 countries, from $-2.9 \%$ year $^{-1}$ (Germany) to $-6.0 \%$ year ${ }^{-1}$ (Slovenia). For $\mathrm{NO}_{x}$, the highest decrease was observed in the United Kingdom $\left(-3.4 \%\right.$ year $\left.^{-1}\right)$, 
while the lowest reduction was found in Lithuania $\left(-0.6 \%\right.$ year $\left.^{-1}\right)$ and Poland $\left(-0.7 \%\right.$ year $\left.^{-1}\right)$. For NMVOCs, the decrease ranged from $-0.6 \%$ year $^{-1}$ (Poland) to $-4.0 \%$ year $^{-1}$ (France). A slight decrease was also observed in Ireland $\left(-0.7 \%\right.$ year $\left.^{-1}\right)$, Netherlands and Romania $\left(-0.9 \%\right.$ year $\left.^{-1}\right)$. The sector "agriculture" contributes to $92 \%$ of $\mathrm{NH}_{3}$ emissions (EEA, 2019), and their emissions usually exhibited small reductions, with an increase in Austria, Estonia, Germany, Latvia, and Lithuania, ranging from 0.1 to $1.0 \%$ year $^{-1}$. The domestic heating represents $48 \%$ of $C O$ emissions (EEA, 2019). Also, the CO emissions usually decreased, except in Romania $\left(-0.5 \%\right.$ year $\left.^{-1}\right)$ and Malta $\left(+0.6 \%\right.$ year $\left.^{-1}\right)$. A decrease of $\mathrm{PM}_{2.5}$ emissions was observed in all EU-28 countries, except Bulgaria $\left(+0.5 \%\right.$ year $\left.^{-1}\right)$, Hungary $\left(+0.9 \%\right.$ year $\left.^{-1}\right)$ and Romania $\left(+0.3 \%\right.$ year $\left.^{-1}\right)$, associating with a slighter reduction in $\mathrm{PM}_{10}$ emissions $\left(-0.2 \%\right.$ year $^{-1}$ in Bulgaria; $-0.1 \%$ year $^{-1}$ in Hungary). An increase of $\mathrm{PM}_{10}$ emissions was noted in Lithuania (+ $0.8 \%$ year ${ }^{1}$ ) and Romania $\left(+0.1 \%\right.$ year $\left.^{-1}\right)$. The highest decrease for $\mathrm{PM}_{2.5}\left(-4.2 \%\right.$ year $\left.^{-1}\right)$ and $\mathrm{PM}_{10}\left(4.0 \%\right.$ year $\left.{ }^{-1}\right)$ emissions occurred in Malta (Table 2). 
Table 2

Annual trends of national emissions (\% year $\left.{ }^{-1}\right)$ in the 28 European Union countries (EU-

28) for sulfur oxides $\left(\mathrm{SO}_{x}\right)$, nitrogen oxides $\left(\mathrm{NO}_{\mathrm{x}}\right)$, non-methane volatile organic compounds (NMVOCs), ammonia $\left(\mathrm{NH}_{3}\right)$, carbon monoxide (CO), particulate matter with an aerodynamic diameter lower than $2.5 \mu \mathrm{m}$ and $10 \mu \mathrm{m}\left(\mathrm{PM}_{2.5}\right.$ and $\left.\mathrm{PM}_{10}\right)$ over the time period 2000-2017. All trends are significant at $p<0.05$ (Mann-Kendall). The increasing trends are in bold.

\begin{tabular}{|lccccccc|}
\hline EU-28 Countries & $\mathrm{SO}_{\mathbf{x}}$ & $\mathrm{NO}_{\mathbf{x}}$ & $\mathrm{NMVOCs}$ & $\mathrm{NH}_{3}$ & $\mathrm{CO}$ & $\mathrm{PM}_{2.5}$ & $\mathrm{PM}_{10}$ \\
\hline Austria & -3.83 & -2.11 & -2.41 & +0.51 & -1.57 & -2.31 & -1.74 \\
\hline Belgium & -4.98 & -3.12 & -3.20 & -1.07 & -3.85 & -2.53 & -2.45 \\
\hline Bulgaria & -5.35 & -2.41 & -1.47 & -0.54 & -1.59 & +0.47 & -0.19 \\
\hline Croatia & -4.84 & -2.63 & -2.25 & -1.34 & -2.85 & -1.71 & -1.72 \\
\hline Cyprus & -4.58 & -1.77 & -2.23 & -1.22 & -3.65 & -3.03 & -3.39 \\
\hline Czech Republic & -3.15 & -2.60 & -1.60 & -0.96 & -1.27 & -0.99 & -1.16 \\
\hline Denmark & -4.45 & -3.35 & -2.30 & -1.48 & -3.00 & -1.49 & -1.13 \\
\hline Estonia & -3.92 & -1.88 & -2.48 & +0.24 & -2.07 & -3.01 & -3.41 \\
\hline Finland & -3.77 & -2.92 & -3.23 & -0.64 & -2.51 & -2.17 & -1.88 \\
\hline France & -4.85 & -3.12 & -3.96 & -0.30 & -3.75 & -3.37 & -2.87 \\
\hline Germany & -2.93 & -1.86 & -2.07 & +0.13 & -2.29 & -2.48 & -1.67 \\
\hline Greece & -5.59 & -2.79 & -3.36 & -1.11 & -3.46 & -2.94 & -3.25 \\
\hline Hungary & -4.59 & -2.35 & -2.04 & -0.44 & -3.00 & +0.93 & -0.10 \\
\hline Ireland & -5.97 & -2.40 & -0.75 & -0.26 & -3.84 & -2.33 & -1.94 \\
\hline Italy & -5.63 & -3.40 & -2.63 & -1.12 & -3.03 & -1.07 & -1.40 \\
\hline Latvia & -4.94 & -1.63 & -1.73 & +0.61 & -3.49 & -2.16 & -1.36 \\
\hline Lithuania & -3.60 & -0.61 & -1.35 & +1.01 & -1.39 & -1.49 & +0.79 \\
\hline Luxembourg & -4.18 & -3.25 & -2.02 & -0.84 & -2.80 & -3.00 & -2.42 \\
\hline Malta & -5.66 & -2.37 & -2.06 & -1.86 & +0.60 & -4.20 & -3.95 \\
\hline Netherlands & -4.14 & -2.72 & -0.88 & -1.76 & -1.78 & -3.53 & -2.65 \\
\hline Poland & -3.62 & -0.69 & -0.62 & -0.81 & -1.67 & -0.72 & -0.79 \\
\hline Portugal & -5.73 & -3.06 & -2.46 & -1.34 & -3.50 & -1.96 & -2.56 \\
\hline Romania & -4.94 & -1.77 & -0.95 & -0.67 & -0.55 & +0.28 & +0.15 \\
\hline
\end{tabular}




\begin{tabular}{|lccccccc|}
\hline EU-28 Countries & $\mathrm{SO}_{\mathbf{x}}$ & $\mathrm{NO}_{\mathbf{x}}$ & NMVOCs & $\mathrm{NH}_{3}$ & $\mathrm{CO}$ & $\mathrm{PM}_{2.5}$ & $\mathrm{PM}_{10}$ \\
\hline Slovakia & -4.46 & -2.31 & -2.69 & -0.98 & -2.36 & -3.22 & -3.06 \\
\hline Slovenia & -6.03 & -2.50 & -2.70 & -0.89 & -2.79 & -0.52 & -1.22 \\
\hline Spain & -5.44 & -2.99 & -2.62 & -0.82 & -2.08 & -1.30 & -1.63 \\
\hline Sweden & -3.71 & -2.32 & -2.15 & -0.66 & -2.77 & -2.54 & -1.64 \\
\hline United Kingdom & -5.26 & -3.42 & -3.28 & -0.52 & -4.21 & -1.40 & -1.70 \\
\hline EU-28 & -4.74 & -2.67 & -2.63 & -0.65 & -2.89 & -1.76 & -1.70 \\
\hline
\end{tabular}

The emissions of all primary air pollutants contributing to ambient levels of $\mathrm{PM}, \mathrm{O}_{3}$, and $\mathrm{NO}_{2}$ decreased between 2000 and 2017 in the EU-28 (observed reductions SO : - 80\%; $\mathrm{NO}_{\mathrm{x}}$ : - 46\%; NMVOCs: - 44\%; $\mathrm{NH}_{3}$ : $-10 \%$; CO: $-49 \%$; $\mathrm{PM}_{2.5}:-31 \%$; $\left.\mathrm{PM}_{10}:-29 \%\right)$, in line with stringent EC Directives, e.g. Air Quality Framework Directive (1996/62/EC), Large Combustion Plant Directive (2001/80/EC), and National Emission Ceilings Directives (2001/81/EC; 2016/2284/EC), setting emission reduction commitments by 2030 compared to 2005 (expected reductions $\mathrm{SO}_{2}$ : - 79\%; NO;: - 63\%; NMVOCs: $-40 \%$; $\mathrm{NH}_{3}$ : $-19 \%$; $\mathrm{PM}_{2.5}$ : $\left.-49 \%\right)$. The emission reductions were mainly achieved as a result of the progress in e.g. the use of flue-gas abatement techniques, energy production and distribution, storage and distribution of solvents (Vestreng et al., 2008; EEA, 2014), and vehicle technologies related to legislative "Euro" standards (Sicard et al., 2020a). In EU-28 countries, the "transport" sector is the largest contributor (road transport: $39 \%$ ) to total $\mathrm{NO}_{\mathrm{x}}$ emissions (EEA, 2019). The Euro-2 to Euro-6 standards for light-duty vehicles were enforced from 1997 to 2015. For diesel cars, the average $\mathrm{NO}_{\mathrm{x}}+$ VOCs limit ranged from $0.70 \mathrm{~g} / \mathrm{km}$ (Euro-2) to $0.17 \mathrm{~g} / \mathrm{km}$ (Euro-6), from $1.00 \mathrm{~g} / \mathrm{km}$ to $0.50 \mathrm{~g} / \mathrm{km}$ for $\mathrm{CO}$ and from $0.08 \mathrm{~g} / \mathrm{km}$ to $0.0045 \mathrm{~g} / \mathrm{km}$ for PM. For gasoline cars, the average $\mathrm{NO}_{\mathrm{x}}+$ VOCs limit ranged from $0.500 \mathrm{~g} / \mathrm{km}$ (Euro-2) and $0.128 \mathrm{~g} / \mathrm{km}$ (Euro-6) and from $2.2 \mathrm{~g} / \mathrm{km}$ to $1.0 \mathrm{~g} / \mathrm{km}$ for CO. In 2017, the successive Euro standards have lowered the PM (94\%), CO (50\%) and $\mathrm{NO}_{\mathrm{x}}+$ VOCs (76\%) emission intensity in the EU compared to early 2000 s.

\section{Trends in urban population exposure}

Despite the reduction of $\mathrm{PM}_{10}$ emissions over the time period 2000-2017, the minimum and maximum percentage of the EU-28 urban population exposed to $\mathrm{PM}_{10}$ concentrations above the EU daily limit value ranged from $18-44 \%$ in $2000-2010$ to $13-30 \%$ in $2010-2017$ (Fig. 1), with the highest extent of exposure observed in 2003 (44\%). Between 2000 and 2017, the EU daily limit value for $\mathrm{PM}_{10}$ was widely exceeded in Europe, mostly in Eastern Europe (Guerreiro et al., 2014), e.g. Bulgaria, Cyprus, Czech Republic, Hungary, Poland, Slovakia, Greece, and Italy. In 2005, Estonia, Finland, Ireland, Luxembourg, and the United Kingdom did not record exceedances of this limit value. In 2017, the limit value was exceeded in Bulgaria, Croatia, Czech Republic, Poland and Italy (EEA, 2011-2019). Before 2006, more than $80 \%$ of the EU-28 population was exposed to levels exceeding the WHO AQG value for the protection of human 
health, decreasing to 42-52\% in 2014-2017 (EEA, 2007; 2011-2019). From 2000 to 2017, the annual averaged $\mathrm{PM}_{10}$ concentrations decreased by $0.65 \mathrm{\mu g} \mathrm{m}^{-3}$ year $^{-1}$ on average at urban stations in the EU28 (EEA, 2019). In 20102017, 6-14\% of the EU28 population was exposed to $\mathrm{PM}_{2.5}$ levels above the EU annual target value, while the range was $16-52 \%$ in $2000-2010$. The target value was exceeded mostly in Bulgaria, Czech Republic, Poland, and Slovakia between 2000 and 2013. The population exposure to $\mathrm{PM}_{2.5}$ levels above the WHO AQG ranged from more than $90 \%$ before 2006 to $74-80 \%$ in $2014-2017$. Between 2000 and 2017, the annual averaged concentrations of $\mathrm{PM}_{2.5}$ decreased by on average $0.42 \mu \mathrm{g}$ $\mathrm{m}^{-3}$ per year at urban background stations in the EU-28 (EEA, 2019).

The percentage of the EU-28 population exposed to $\mathrm{NO}_{2}$ concentrations above the $\mathrm{EU}$ annual limit value and the WHO AQG value decreased from $14-31 \%$ before 2006 , with the maximum recorded in 2003 , to less than $10 \%$ since 2012 (Fig. 1). The annual limit value was mostly exceeded in Italy, Greece, and in the United Kingdom in 2000-2005, and in Germany in 2010, 2011, 2012, 2014, and 2016 (EEA, 2011-2019). The $\mathrm{NO}_{2}$ annual mean concentrations decreased by on average $0.39 \mu \mathrm{g} \mathrm{m}^{-3}$ year $^{-1}$ over the time period 2002-2011 by joining 708 urban stations in the EU-28 (Guerreiro et al., 2014). The percentage of the EU28 urban population exposed to $\mathrm{SO}_{2}$ levels above the $\mathrm{EU}$ daily limit value ranged from 1-2\% in $2000-$ 2005 to lower than $0.5 \%$ since 2007 (data not shown). The percentage of the EU-28 urban population exposed to $\mathrm{SO}_{2}$ levels exceeding the WHO AQG decreased from more than 70\% before 2006 to less than $40 \%$ since 2013 (EEA, 2011-2019). Less than $2 \%$ of the EU-28 urban population was exposed to maximum $\mathrm{CO}$ daily 8-hour mean concentrations above the EU and the WHO AQG limit values (data not shown). Only a few traffic stations in Bulgaria, Poland and Romania have reported exceedances of the $\mathrm{SO}_{2}$ and CO EU limit values over the time period 2000-2017 (Guerreiro et al., 2014; EEA, 2019).

The EU-28 urban population exposed to $\mathrm{O}_{3}$ levels above the $\mathrm{EU}$ target value for human health protection ranged from 7-62\% since 2000 (Fig. 1), with the highest extent of exposure observed in 2003. Higher background $\mathrm{O}_{3}$ levels (annual mean $>30 \mathrm{ppb}$ ) were observed in Southern Europe (Sicard et al., 2013). The EU target value was mostly exceeded in Southern Europe, such as Croatia, Cyprus, France, Greece, Italy, Slovenia, Spain, Malta, Portugal, but also in Austria, Hungary, Luxembourg, and Poland recently. More than $95 \%$ of the total EU-28 urban population was exposed to $\mathrm{O}_{3}$ levels exceeding the WHO AQG since 2000 (data not shown). In the $\mathrm{EU}$, the annual mean of daily $\mathrm{O}_{3}$ concentrations increased by on average 0.05 ppb year $^{-1}$ at 260 urban stations over the time period 2000-2014 (Table 3). The annual $\mathrm{O}_{3}$ mean concentrations increased by on average $0.34 \mathrm{ppb}$ year $^{-1}$ at more than $80 \%$ of urban stations between 2005 and 2014, except in the United Kingdom where a decrease (- 0.18 ppb year $\left.^{-1}\right)$ was observed at $65 \%$ of urban stations (Sicard et al., 2020a). In Germany, an increase of 0.18 ppb year $^{-1}$ was reported at 79 urban stations over the time period 2005-2018 (Sicard et al., 2020a). A significant increase in the annual $\mathrm{O}_{3}$ mean (on average, $+0.29 \mathrm{ppb}$ year $^{-1}$ ) was found at urban stations in Southern Europe between 2000 and 2010 (Sicard et al., 2013; Kulkarni et al. 2015). In France, an increase of +0.14 ppb year ${ }^{-1}$ at $76 \%$ of urban stations was reported between 1999 and 2012 (Sicard et al., 2016b). Despite an increasing fleet 
size, the reduction in $\mathrm{NO}_{x}$ and VOCs emissions since the early 1990s, due to the vehicle emission regulations, allowed a reduction in $\mathrm{O}_{3}$ peaks and high percentiles (EEA, 2016; Sicard et al., 2018; de Foy et al., 2020). At EU-28 urban stations, a reduction in $\mathrm{O}_{3}$ annual mean of the maximum daily 8-hour mean values (- 0.75 ppb year $\left.^{-1}\right)$ was found over the time period 2000-2014 (EEA, 2016). In Southern Europe, significant reductions in 98 th percentile $\left(-0.51\right.$ ppb year $\left.^{-1}\right)$ and hourly maximum $\left(-1.81\right.$ ppb year $\left.^{-1}\right)$ values were found at urban stations between 2000 and 2010 (Sicard et al., 2013). Simpson et al. (2014) found an increase of $\mathrm{O}_{3}$ concentrations of $0.1-0.4 \mathrm{ppb}$ year $^{-1}$ up to the 95 th $\mathrm{O}_{3}$ percentile over the time period 1990-2009. The surface $\mathrm{O}_{3}$ levels are rising in cities in Europe from 2000 (e.g. Simon et al., 2015; Sicard et al., 2016b; Chang et al., 2017; Lefohn et al., 2018; Yan et al., 2019; Sicard et al., 2020a), mainly due to a reduced titration of $\mathrm{O}_{3}$ by NO (Huszar et al., 2015; Sicard et al., 2020a). 
Table 3

National-averaged trends magnitude ( $\mathrm{ppb}$ per year \pm standard deviation) of annual ozone mean concentrations at urban and rural background monitoring stations worldwide. The studies were selected for more than 10-year time-series of ozone data, for stations with at least $75 \%$ of validated hourly data over the time period, and with a significant trend, i.e. with a $p$-value $<0.05$. Number of stations ( $\mathrm{n}$, with $\mathrm{n}$ $\geq 2$ ).

\begin{tabular}{|c|c|c|c|c|}
\hline Countries & Time period & References & $\mathbf{n}$ & Urban stations \\
\hline Europe & 1995-2012 & Yan et al., 2019 & 289 & $+0.27 \pm 0.10$ \\
\hline Austria & \multirow[t]{10}{*}{$1995-2014$} & \multirow[t]{10}{*}{ Sicard et al., 2018} & 6 & $+0.17 \pm 0.12$ \\
\hline Belgium & & & 2 & $+0.08 \pm 0.15$ \\
\hline Germany & & & 60 & $+0.19 \pm 0.06$ \\
\hline Greece & & & 3 & $+0.18 \pm 0.50$ \\
\hline Netherlands & & & 5 & $+0.19 \pm 0.11$ \\
\hline Slovenia & & & 2 & $+0.14 \pm 0.08$ \\
\hline Spain & & & 12 & $+0.36 \pm 0.24$ \\
\hline Sweden & & & 3 & $+0.37 \pm 0.10$ \\
\hline Switzerland & & & 11 & $+0.28 \pm 0.11$ \\
\hline United Kingdom & & & 12 & $+0.21 \pm 0.12$ \\
\hline France & 1999-2012 & Sicard et al., 2016b & 179 & $+0.14 \pm 0.19$ \\
\hline France & \multirow[t]{5}{*}{$2000-2010$} & Kulkarni et al., 2015 & 29 & $+0.10 \pm 0.30$ \\
\hline Greece & & \multirow[t]{4}{*}{ Sicard et al., 2013} & 3 & $+0.41 \pm 0.15$ \\
\hline Italy & & & 20 & $+0.04 \pm 0.30$ \\
\hline Portugal & & & 8 & $+0.40 \pm 0.33$ \\
\hline Spain & & & 14 & $+0.48 \pm 0.53$ \\
\hline Europe & $2000-2014$ & Chang et al., 2017 & 260 & $+0.05 \pm 0.13$ \\
\hline Belgium & \multirow[t]{6}{*}{$2005-2014$} & \multirow[t]{6}{*}{ Sicard et al., 2020a } & 2 & $+0.42 \pm 0.05$ \\
\hline France & & & 136 & $+0.31 \pm 0.42$ \\
\hline Germany & & & 79 & $+0.09 \pm 0.17$ \\
\hline Greece & & & 4 & $+0.85 \pm 0.43$ \\
\hline Italy & & & 50 & $+0.43 \pm 0.84$ \\
\hline Portugal & & & 2 & $+0.48 \pm 0.12$ \\
\hline
\end{tabular}




\begin{tabular}{|lllll|}
\hline Countries & Time period & References & $\mathbf{n}$ & Urban stations \\
\hline Spain & & & 77 & $+0.54 \pm 0.73$ \\
\cline { 1 - 1 } United Kingdom & & & 29 & $-0.18 \pm 0.34$ \\
\cline { 1 - 3 } Germany & $2005-2018$ & Sicard et al., 2020a & 79 & $+0.18 \pm 0.15$ \\
\hline
\end{tabular}

\section{Trends in national mortality from exposure to ambient $\mathrm{PM}_{2.5}$ and $\mathrm{O}_{3}$ levels}

At present compared to other air pollutants, $\mathrm{PM}_{2.5}$ poses the most serious health risk in the EU-28 cities, associated with premature deaths and increased morbidity, followed by ground-level $\mathrm{O}_{3}$ (Pascal et al., 2013; Cohen et al., 2017). In the EU-28, the number of deaths due to ambient $\mathrm{PM}_{2.5}$ levels decreased by on average 4.85 per 1,000,000 inhabitants annually between 2000 and 2017 (Table 4). The highest annual decreases were observed in the United Kingdom and Estonia ( -11.74 and -10.46 deaths per $10^{6}$ inhabitants, respectively) while a slighter reduction was found in Portugal ( -0.50 deaths per $10^{6}$ inhabitants). In Greece and Lithuania, an increase of annual mortality due to ambient $\mathrm{PM}_{2.5}$ levels was observed $\left(+1.22\right.$ and +1.72 deaths per $10^{6}$ inhabitants, respectively). In line with rising $\mathrm{O}_{3}$ levels in cities (Sicard et al., 2018, 2020a), the annual $\mathrm{O}_{3}$-related number of premature deaths increased in the EU-28 (on average +0.55 deaths per $10^{6}$ inhabitants). The highest annual decrease of mortality was observed in Greece ( +2.41 deaths per $10^{6}$ inhabitants), Hungary $\left(+2.05\right.$ deaths per $10^{6}$ inhabitants) and Czech Republic ( +1.40 deaths per $10^{6}$ inhabitants), while a non-significant increase was found in Spain $(+0.03$ deaths per $10^{6}$ inhabitants). Between 2000 and 2017, the annual number of deaths attributed to $\mathrm{O}_{3}$ declined mostly in Northern Europe (e.g. Belgium: - 0.24; Ireland: - 0.30; Lithuania: -0.23 deaths per $10^{6}$ inhabitants per year) where lower background $\mathrm{O}_{3}$ levels (annual mean $<20 \mathrm{ppb}$ ) were observed (Araminienè et al., 2019; Sicard et al., 2020a). 
Table 4

Annual trends of mortality (number of deaths per 1,000,000 inhabitants per year) due to ambient particulate matter with an aerodynamic diameter lower than $2.5 \mu \mathrm{m}\left(\mathrm{PM}_{2.5}\right)$ and tropospheric ozone $\left(\mathrm{O}_{3}\right)$ over the time period 2000-2017 in the 28 European Union countries (EU-28) with associated significance level $p$ (Mann-Kendall *** $p<0.001$; ** $p<0.01$; ${ }^{*} \mathrm{p}<0.05 ;+\mathrm{p}<0.1$ and $\left.\mathrm{p}>0.1\right)$.

\begin{tabular}{|c|c|c|c|c|}
\hline EU-28 Countries & $\mathrm{PM}_{2.5}$ & p level & $\mathrm{O}_{3}$ & p level \\
\hline Austria & -6.00 & $\star \star \star \star ~$ & 0.18 & ** \\
\hline Belgium & -8.80 & $* * *$ & -0.24 & * \\
\hline Bulgaria & -2.73 & * & 0.56 & $\star \star \star$ \\
\hline Croatia & -2.27 & + & 1.18 & $\star \star \star$ \\
\hline Cyprus & -9.07 & $\star \star \star *$ & 0.14 & \\
\hline Czech Republic & -4.56 & $\star * *$ & 1.40 & $\star \star \star$ \\
\hline Denmark & -9.42 & $\star * *$ & 0.18 & \\
\hline Estonia & -10.46 & $\star \star \star \star ~$ & 0.20 & $\star \star \star ~$ \\
\hline Finland & -6.55 & $* \star *$ & 0.22 & $\star \star \star$ \\
\hline France & -3.55 & $* \star *$ & 0.09 & \\
\hline Germany & -3.11 & $\star \star \star *$ & 1.19 & $\star \star \star \star ~$ \\
\hline Greece & 1.22 & * & 2.41 & $\star \star \star$ \\
\hline Hungary & -1.39 & & 2.05 & $\star \star \star$ \\
\hline Ireland & -9.05 & $\star \star \star$ & -0.30 & + \\
\hline Italy & -2.28 & $\star \star$ & 0.75 & $\star \star \star$ \\
\hline Latvia & -5.40 & * & 0.20 & $\star \star \star$ \\
\hline Lithuania & 1.72 & + & -0.23 & $\star \star \star ~$ \\
\hline Luxembourg & -8.05 & $\star \star \star$ & -0.17 & * \\
\hline Malta & -0.38 & & 0.32 & $\star \star \star \star$ \\
\hline Netherlands & -8.76 & $\star \star \star$ & 0.24 & * \\
\hline Poland & -9.56 & $\star \star \star ~$ & 0.45 & $\star \star \star$ \\
\hline Portugal & -0.50 & & 0.37 & $\star \star \star \star ~$ \\
\hline Romania & -4.04 & $* * *$ & 0.37 & $\star \star \star$ \\
\hline
\end{tabular}




\begin{tabular}{|c|c|c|c|c|}
\hline EU-28 Countries & $\mathrm{PM}_{2.5}$ & p level & $\mathrm{O}_{3}$ & $p$ level \\
\hline Slovakia & -7.56 & $\star \star \star \star$ & 0.42 & $\star \star \star$ \\
\hline Slovenia & -5.74 & $\star \star \star \star$ & -0.67 & $\star \star \star$ \\
\hline Spain & -5.04 & $\star \star \star$ & 0.03 & \\
\hline Sweden & -8.44 & $\star \star \star \star$ & 0.32 & $\star \star \star \star$ \\
\hline United Kingdom & -11.74 & $\star \star \star \star$ & 0.08 & \\
\hline EU-28 & -4.85 & $\star \star \star *$ & 0.55 & $\star * *$ \\
\hline
\end{tabular}

\section{Conclusions}

In the EU-28, $\mathrm{SO}_{x}, \mathrm{NO}_{x}, \mathrm{NMVOCs} \mathrm{NH}_{3}, \mathrm{CO}, \mathrm{PM}_{2.5}$ and $\mathrm{PM}_{10}$ emissions fell by about $80 \%, 46 \%, 44 \%, 10 \%$, $49 \%, 31 \%$ and $29 \%$, respectively, over the time period $2000-2017$, thus confirming successful control strategies of air pollutants emissions. However, the current levels of air pollutants in cities continue to exceed the EU standards and WHO AQG for the protection of human health in Europe, especially for secondary air pollutants such as $\mathrm{PM}_{2.5}$ and $\mathrm{O}_{3}$ (Guerreiro et al., 2014; De Marco et al., 2018; EEA, 2018; Sicard et al., 2019). In 2015-2017, the percentages of EU-28 urban population exposed to concentrations exceeding the WHO limit values were $74-81 \%$ for $\mathrm{PM}_{2.5}, 42-52 \%$ for $\mathrm{PM}_{10}, 95-98 \%$ for $\mathrm{O}_{3}, 21-31 \%$ for $\mathrm{SO}_{2}$ and $7-8 \%$ for $\mathrm{NO}_{2}$ (EEA, 2019). In agreement with a reduction of ambient $\mathrm{PM}_{2.5}$ levels in cities, the

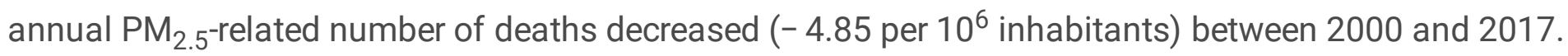
The control strategies of $\mathrm{O}_{3}$ precursor emissions were effective in rural areas (Sicard et al., 2013; Paoletti et al., 2014). However, the rising $\mathrm{O}_{3}$ levels have become a major public health issue in the EU-28 cities (Lefohn et al., 2018; Sicard et al., 2018, 2020a), where the annual $\mathrm{O}_{3}$-related number of premature deaths increased ( +0.55 deaths per $10^{6}$ inhabitants).

There is an urgent need to take decisive actions at all governance levels to achieve the objectives of the Ambient Air Quality Directives as reported by the EC (COM(2018)330 "A Europe that protects: Clean air for all"). These actions span from improving air quality monitoring network, control of emission sources, improved mobility plans and raising awareness to citizens on the problem of air pollution, among others. In this context, urban and peri-urban reforestation can help improve air quality and meet air quality standards in cities (Nowak, 2006; Escobedo et al., 2011; Baró et al., 2014), but also answer to social needs, e.g. recreation, cultural, aesthetic (Selmi et al., 2016; Samson et al., 2019).

Although outside the period of analysis, it is relevant to note that the recent COVID-19 pandemic could represent an opportunity for adopting measures that contribute to improve air quality in European cities in the future. Compared to the same period in 2017-2019, the lockdown measures in 2020 led to a decrease of $\mathrm{NO}(\sim 63 \%)$ and $\mathrm{NO}_{2}(\sim 52 \%)$ concentrations in Southern European cities due to the reduction of road and non-road transport (Sicard et al. 2020b; Tobías et al., 2020). However, these measures did not 
significantly reduce the $\mathrm{PM}_{2.5}$ and $\mathrm{PM}_{10}$ levels ( 8\%) attributed to an increase of $\mathrm{PM}$ emissions from the activities at home (e.g. domestic heating, biomass burning), and during the lockdown, the ground-level $\mathrm{O}_{3}$ levels increased by $\sim 17 \%$ due to a lower titration of $\mathrm{O}_{3}$ by NO (Sicard et al. 2020b). While it is true that "Air pollution rebounds in Europe's cities as lockdowns ease" (Financial Times, 24 June 2020) and that COVID discourages the use of public transport, there are some positive changes that, if sustained over time, might result in improvements of air quality in the cities in the future. Partial or total telework has been implemented in many companies and public offices, a change that will last to certain extent after the COVID pandemic reducing private car mobility. Cities like Barcelona and Paris have widened sidewalks to ensure social distancing on pedestrians, created more bicycle lanes and separated traffic and bus lanes for each direction ${ }^{4}$.

The COVID-19 lockdowns showed us the value of green urban spaces for our physical and mental wellbeing. Greening and re-naturing cities are keywords of the EU Biodiversity Strategy for 2030 (EC

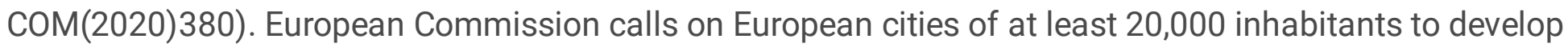
"ambitious Urban Greening Plans" by including the promotion of green infrastructure, nature-based solutions, and by planting at least 3 billion additional trees in the EU by 2030 . However, to efficiently reduce air pollution in cities, municipalities and city planners urgently need to base the selection of tree species upon quantitative and concrete assessments of the role of urban trees in affecting air quality either positively or negatively (Sicard et al., 2018). Then, the COVID pandemic can be taken as an opportunity for the cities to foster changes in organization of the urban public space and re-think mobility (Honey-Rosés et al., 2020), which hopefully may have relevant and lasting impacts on the quality of urban air.

${ }^{4}$ http://www.xinhuanet.com/english/2020-05/19/c_139070452.htm; https://www.rfi.fr/en/france/20200520-france-bicycle-use-jumps-44-percent-since-end-coronavirusconfinement-paris-anne-hidalgo

\section{Abbreviations}

AP: attributable proportion, AQG: Air Quality Guidelines, BI: baseline incidence, CAPE: The Clean Air Programme for Europe, CLRTAP: Convention on Long-range Transboundary Air Pollution, CO: carbon monoxide, EEA: European Environmental Agency, EMEP: European Monitoring and Evaluation Program, EU: European Union, GDB: Global Burden of Diseases, $N C_{c}$ : number of cases attributed to the exposure to the air pollutant $c, \mathrm{NH}_{3}$ : ammonia, NMVOCs: non-methane volatile organic compounds, $\mathrm{NO}_{\mathrm{x}}$ : nitrogen oxides, $\mathrm{O}_{3}$ : tropospheric ozone, OECD: Organization for Economic Co-operation and Development, $\mathrm{PM}_{10}$ : particulate matter with an aerodynamic diameter lower than $10 \mu \mathrm{m}, \mathrm{PM}_{2.5}$ : particulate matter with an aerodynamic diameter lower than $2.5 \mu \mathrm{m}$, RR: relative risk, $\mathrm{SO}_{\mathrm{x}}$ : sulfur oxides, WHO: World Health Organization.

\section{Declarations}


Ethics approval and consent to participate -

Not applicable

Consent for publication -

Not applicable

\section{Availability of data and materials -}

Not applicable

\section{Competing interests -}

The authors declare that they have no known competing financial interests or personal relationships that could have appeared to influence the work reported in this paper.

\section{Funding -}

This work was carried out with the contribution of the LIFE financial instrument of the European Union in the framework of the AIRFRESH project "Air pollution removal by urban forests for a better human wellbeing” (LIFE19 ENV/FR/000086). V.C. thanks Project IMAGINA (PROMETEU 2019, Generalitat Valenciana).

\section{Authors' contributions -}

P.S., V.C., and E.A. conceived the project. P.S., V.C., and E.A. analyzed the data. All authors participated in writing and revising the manuscript.

\section{Acknowledgements -}

This work was made in the framework of the Research Group 8.04.00 "Air Pollution and Climate Change" and Working Party 8.04.05 "Ground-level ozone" under the International Union of Forest Research Organizations.

\section{References}

1. Agathokleous E., Feng Z., Oksanen E., Sicard P., Wang Q., Saitanis C.J., et al., 2020, “Ozone affects plant, insect, and soil microbial communities: A threat to terrestrial ecosystems and biodiversity". Science Advances 6: eabc1176.

2. Amoatey P., Sicard P., De Marco A., Khaniabadi Y.O., 2019a, "Human health risk assessment of longterm exposures to $\mathrm{PM}_{2.5}$ in Rome, Italy". Clinical Epidemiology and Global Health 7: 222227. Amoatey P., Takdastan A., Sicard P., Hopke P.K., Baawain M., Omidvarborna H., De Marco A., 
Allahyari S., Khanaibadi Y.O., 2019b, "Short and long-term impacts of ambient ozone on health in Ahvaz, Iran". Human and Ecological Risk Assessment: 1-16.

3. Araminienè V., Sicard P., Anav A., Agathokleous E., Stakenas V., De Marco A., et al., 2019, "Trends and inter-relationships of ground-level ozone metrics and forest health in Lithuania". Science of the Total Environment 658: 1265-1277.

4. Baró F., Chaparro L., Gómez-Baggethun E., Langemeyer J., Nowak D.J., Terradas J., 2014, "Contribution of Ecosystem Services to Air Quality and Climate Change Mitigation Policies: The Case of Urban Forests in Barcelona, Spain". Ambio 43: 466-479.

5. Chang K.L., Petropavlovskikh I., Cooper O.R., Schultz M.G., Wang, T., 2017, "Regional trend analysis of surface ozone observations from monitoring networks in eastern North America, Europe and East Asia". Elementa: Science of the Anthropocene 5, p.50

6. Cohen A.J., Brauer M., Burnett R., Anderson H.R., Frostad J., Estep K., et al., 2017, "Estimates and 25year trends of the global burden of disease attributable to ambient air pollution: an analysis of data from the Global Burden of Diseases Study 2015". Lancet 389: 1907-1918.

7. Convention on Long-range Transboundary Air Pollution, 2017. “Mapping Critical Levels for Vegetation". Chapter III of manual on methodologies and criteria for modelling and mapping critical loads and levels and air pollution effects, risks and trends. UNECE.

8. de Foy B., Brune W.H., Schauer J.J., 2020, "Changes in ozone photochemical regime in Fresno, California from 1994 to 2018 deduced from changes in the weekend effect". Environmental Pollution 263: 114380.

9. De Marco A., Sicard P., Khaniabadi Y.O., Hopke P.K., Amoatey P., 2018, "Mortality and morbidity for cardiopulmonary diseases related to $\mathrm{PM}_{2.5}$ exposure in the metropolis of Rome, Italy". European Journal of Internal Medicine 57: 49-57.

10. European Commission, $\operatorname{COM(2020)} 380$ final "EU Biodiversity Strategy for 2030 - Bringing nature back into our lives". Brussels, 20.5.2020.

11. European Commission, 2018, $\operatorname{COM(2018)~} 330$ final "A Europe that protects: Clean air for all". Brussels, 17.5.2018.

12. European Commission, 2013, COM(2013) 918 final "A Clean Air Programme for Europe". Brussels, 18.12.2013.

13. European Council Directive 2016/2284/EC of the European Parliament and of the Council of 14 December 2016 on the reduction of national emissions of certain atmospheric pollutants, amending Directive 2003/35/EC and repealing Directive 2001/81/EC. Official Journal of the European Union L 344/1 17.12.2016.

14. European Council Directive 2008/50/EC of the European Parliament and of the Council of 21May 2008 on ambient air quality and cleaner air for Europe. Official Journal L 152, 11.6.2008 P. 00010044.

15. European Council Directive 2001/80/EC of the European Parliament and of the Council of 23 October 2001 on the limitation of emissions of certain pollutants into the air from large combustion plants. 
Official Journal L 309, 27.11.2001 P. 0001-0021.

16. European Council Directive 2001/81/EC of the European Parliament and of the Council of 23 October 2001 on national emission ceilings for certain atmospheric pollutants. Official Journal L 309, 27.11.2001 P. 0022-0030.

17. European Council Directive 1996/62/EC of the European Parliament and of the Council of 27 September 1996 on ambient air quality assessment and management. Official Journal L 296, 21.11.1996 P. 0055-0063.

18. European Environment Agency, 2019, "Air quality in Europe - 2019 report". EEA Technical Report No 10/2019, doi:10.2800/822355.

19. European Environment Agency, 2018, "Air Quality in Europe - 2018 report”. EEA Technical Report No 12/2018, doi: 10.2800/777411.

20. European Environment Agency, 2017, "Air quality in Europe - 2017 report". EEA Technical Report No 13/2017, doi:10.2800/850018.

21. European Environment Agency, 2016 "Air quality in Europe - 2016 report". EEA Technical Report No 28/2016, doi:10.2800/80982.

22. European Environment Agency, 2015 "Air quality in Europe - 2015 report". EEA Technical Report No 5/2015, doi:10.2800/62459.

23. European Environment Agency, 2014 "Air quality in Europe - 2014 report". EEA Technical Report No 5/2014, doi:10.2800/22775.

24. European Environment Agency, 2013 "Air quality in Europe - 2013 report". EEA Technical Report No 9/2013, doi:10.2800/92843.

25. European Environment Agency, 2012 "Air quality in Europe - 2012 report". EEA Technical Report No 4/2012, doi:10.2800/55823.

26. European Environment Agency, 2011 "Air quality in Europe - 2011 report". EEA Technical Report No 12/2011, doi:10.2800/83213.

27. European Environment Agency, 2007 "Air quality in Europe - 1990-2004". EEA Technical Report No 2/2007, ISSN 1725-9177.

28. European Union, 2016, "Urban Europe Statistics on cities, towns and suburbs", Eurostat Statistical book doi: $10.2785 / 91120$.

29. Escobedo F.J., Kroeger T., Wagner J.E., 2011, “Urban forests and pollution mitigation: Analyzing ecosystem services and disservices". Environmental Pollution 159: 2078-2087.

30. Feng Z., De Marco A., Anav A., Gualtieri M., Sicard P., Tian H., et al., 2019, “Economic losses due to ozone impacts on human health, forest productivity and crop yield across China". Environmental International 131: 104966.

31. Global Burden of Disease, 2018, "Global, regional, and national comparative risk assessment of 84 behavioural, environmental and occupational, and metabolic risks or clusters of risks for 195 
countries and territories, 1990-2017: a systematic analysis for the Global Burden of Disease Study 2017". Lancet 392: 1923-1994.

32. Goudarzi G., Daryanoosh S.M., Godini H., Hopke P.K., Sicard P., De Marco A., et al., 2017, "Health risk assessment of exposure to the Middle-Eastern Dust storms in the Iranian megacity of Kermanshah." Public Health 148: 109-116.

33. Guerreiro C.B.B., Foltescu V., de Leeuw F., 2014, "Air quality status and trends in Europe". Atmospheric Environment 98: 376-384.

34. Honey-Rosés J., Anguelovski I., Chireh V.K., Daher C., Konijnendijk van den Bosch C., Litt J.S., et al., 2020, "The impact of COVID-19 on public space: an early review of the emerging questions - design, perceptions and inequities". Cities \& Health, 1-17.

35. Huszar P., Belda M., Halenka T., 2015, "On the long-term impact of emissions from central European cities on regional air-quality". Atmospheric Chemistry and Physics Discussions 15: 32101-32155.

36. Khaniabadi Y.O., Sicard P., Takdastan A., Hopke P.K., Taiwo A.M., Khaniabadi F.O., De Marco A., Daryanoosh M., 2019, "Mortality and morbidity due to ambient air pollution in Iran". Clinical Epidemiology and Global Health 7: 222-227. Khaniabadi Y.O., Daryanoosh M., Sicard P., Takdastan A., Hopke P.K., Esmaeili S., De Marco A., Rashidi R., 2018a, "Chronic obstructive pulmonary diseases related to outdoor $\mathrm{PM}_{10}, \mathrm{O}_{3}, \mathrm{SO}_{2}$ and $\mathrm{NO}_{2}$ in a heavily-polluted megacity of Iran". Environmental Science and Pollution Research 25:17726-17734.

37. Khaniabadi Y.O., Daryanoosh M., Sicard P., Takdastan A., Hopke P.K., Esmaeili S., et al., 2018b, "Chronic obstructive pulmonary diseases related to outdoor $\mathrm{PM}_{10}, \mathrm{O}_{3}, \mathrm{SO}_{2}$ and $\mathrm{NO}_{2}$ in a heavilypolluted megacity of Iran". Environmental Science and Pollution Research 25:17726-17734.

38. Koolen C.D. and Rothenberg G., 2019, "Air Pollution in Europe”. ChemSusChem 10: 164-172.

39. Kulkarni P.S., Bortoli D., Domingues A., Silva A.M., 2015, "Surface Ozone Variability and Trend over Urban and Suburban Sites in Portugal”. Aerosol and Air Quality Research: 1-15.

40. Lefohn A.S., Malley C.S., Smith L., Wells B., Hazucha M., Simon H., et al., 2018, "Tropospheric ozone assessment report: global ozone metrics for climate change, human health, and crop/ecosystem research". Elementa: Science of the Anthropocene 6: 28.

41. Lelieveld J., Evans J.S., Fnais M., Giannadaki D., Pozzer A., 2015, "The contribution of outdoor air pollution sources to premature mortality on a global scale". Nature 525: 367-371.

42. Mills G., Hayes F., Simpson D., Emberson L., Norris D., Harmens H., et al., 2011, “Evidence of widespread effects of ozone on crops and (semi-)natural vegetation in Europe (1990-2006) in relation to AOT40 and flux-based risk maps". Global Change Biology 17: 592-613.

43. Nowak D.J., Crane D.E., Stevens J.C., 2006, "Air pollution removal by urban trees and shrubs in the United States". Urban Forestry \& Urban Greening 4: 115-123.

44. Paoletti E., 2007, "Ozone impacts on forests". CAB Reviews: Perspectives in Agriculture, Veterinary Science, Nutrition and Natural Resources, 2 (No. 68): 13 pp 
45. Paoletti E., De Marco A., Beddows D.C.S., Harrison R.M., Manning W.J., 2014, “Ozone levels in European and USA cities are increasing more than at rural sites, while peak values are decreasing". Environmental Pollution 192: 295-299.

46. Pascal M., Corso M., Chanel O., Declercq C., Badaloni C., Cesaroni G., et al., 2013, "Assessing the public health impacts of urban air pollution in 25 European cities: results of the Aphekom project". Science of the Total Environment 449: 390-400.

47. Samson R., Moretti M., Amorim J.U., BranquinhoC., Fares S., Morelli F., et al., 2019, "Towards an integrative approach to evaluate the environmental ecosystem services provided by urban forests". Journal of Forestry Research 30: 1981-1996.

48. Selmi W., Weber C., Rivière E., Blond N., Mehdi L., Nowak D.J., 2016, “Air pollution removal by trees in public green spaces in Strasbourg city, France”. Urban Forestry \& Urban Greening 17: 192-201.

49. Sicard P., Paoletti E., Agathokleous E., Araminienè V., Proietti C., Coulibaly F., et al., 2020a, “Ozone weekend effect in cities: Deep insights for urban air pollution control". Environmental Research 191: 110193.

50. Sicard P., De Marco A., Agathokleous E., Feng Z., Xu X., Paoletti E., et al., 2020b, “Amplified ozone pollution in cities during the COVID-19 lockdown". Science of the Total Environment 735: 139542.

51. Sicard P., Khaniabadi Y.O., Perez S., Gualtieri M., De Marco A., 2019, "Effect of $\mathrm{O}_{3}, \mathrm{PM}_{10}$ and $\mathrm{PM}_{2.5}$ on cardiovascular and respiratory diseases in cities of France, Iran and Italy". Environmental Science and Pollution Research 26: 32645-32665.

52. Sicard P., Agathokleous E., Araminiene V., Carrari E., Hoshika Y., De Marco A., et al., 2018, "Should we see urban trees as effective solutions to reduce increasing ozone levels in cities?". Environmental Pollution 243: 163-176.

53. Sicard P., Augustaitis A., Belyazid S., Calfapietra C., De Marco A., Fenn M., et al., 2016a, "Global topics and novel approaches in the study of air pollution, climate change and forest ecosystems". Environmental Pollution 213: 977-987.

54. Sicard P., Serra R., Rossello P., 2016b, "Spatio-temporal trends of surface ozone concentrations and metrics in France." Environmental Research 149: 122-144.

55. Sicard P., De Marco A., Troussier F., Renou C., Vas N., Paoletti E., 2013, "Decrease in surface ozone concentrations at Mediterranean remote sites and increase in the cities". Atmospheric Environment 79: 705-715.

56. Sicard P., Coddeville P., Galloo J.C., 2009, "Near-surface ozone levels and trends at rural stations in France over the 1995-2003 period”. Environmental Monitoring and Assessment 156: 141-157.

57. Simon H., Reff A., Wells B., Xing J., Frank N., 2015, “Ozone trends across the United States over a period of decreasing $\mathrm{NO}_{\mathrm{x}}$ and VOC emissions”. Environmental Science \& Technology 49: 186-195.

58. Simpson D., Arneth A., Mills G., Solberg S., Uddling J., 2014,"'Ozone - the persistent menace: interactions with the $\mathrm{N}$ cycle and climate change". Current Opinion in Environmental Sustainability 10: 9-19. 
59. Tobías A., Carnerero C., Reche C., Massagué J., Via M., Minguillón M.C., et al., 2020, “Changes in air quality during the lockdown in Barcelona (Spain) one month into the SARS-CoV-2 epidemic". Science of the Total Environment 726, 138540.

60. Vestreng V., Ntziachristos L., Semb A., Reis S., Isaksen I.S.A., Tarrasón L., 2008, “Evolution of $\mathrm{NO}_{\mathrm{x}}$ emissions in Europe with focus on road transport control measures”. Atmospheric Chemistry and Physics Discussions 8: 10697-10747.

61. World Health Organization, 2018, "AirQ+: software tool for health risk assessment of air pollution".

62. http://www.euro.who.int/en/health-topics/environment-and-health/air-quality/activities/airqsoftware-tool-for-health-risk-assessment-of-air-pollution (accessed 13 September 2020).

63. World Health Organization, 2016, "Global Health Observatory data" https://www.who.int/gho/phe/outdoor_air_pollution/burden/en/ (accessed 13 September 2020).

64. World Health Organization, 2013, "Review of Evidence on Health Aspects of Air Pollution - REVIHAAP Project”. World Health Organization, Regional Office for Europe, Copenhagen, Denmark. Technical Report.

65. World Health Organization, 2008, "Health risks of ozone from long-range transboundary air pollution”. WHO/Euro product ISBN 9789289042895.

66. World Health Organization, 2006, "Air quality guidelines global update 2005: particulate matter, ozone, nitrogen dioxide and sulfur dioxide". Regional Office for Europe (Copenhagen: WHO Regional Office for Europe, 2006).

67. Yan Y., Lin J., Pozzer A., Kong S., Lelieveld J., 2019, "Trend reversal from high-to-low and from ruralto-urban ozone concentrations over Europe”. Atmospheric Environment 213: 25-36.

\section{Figures}




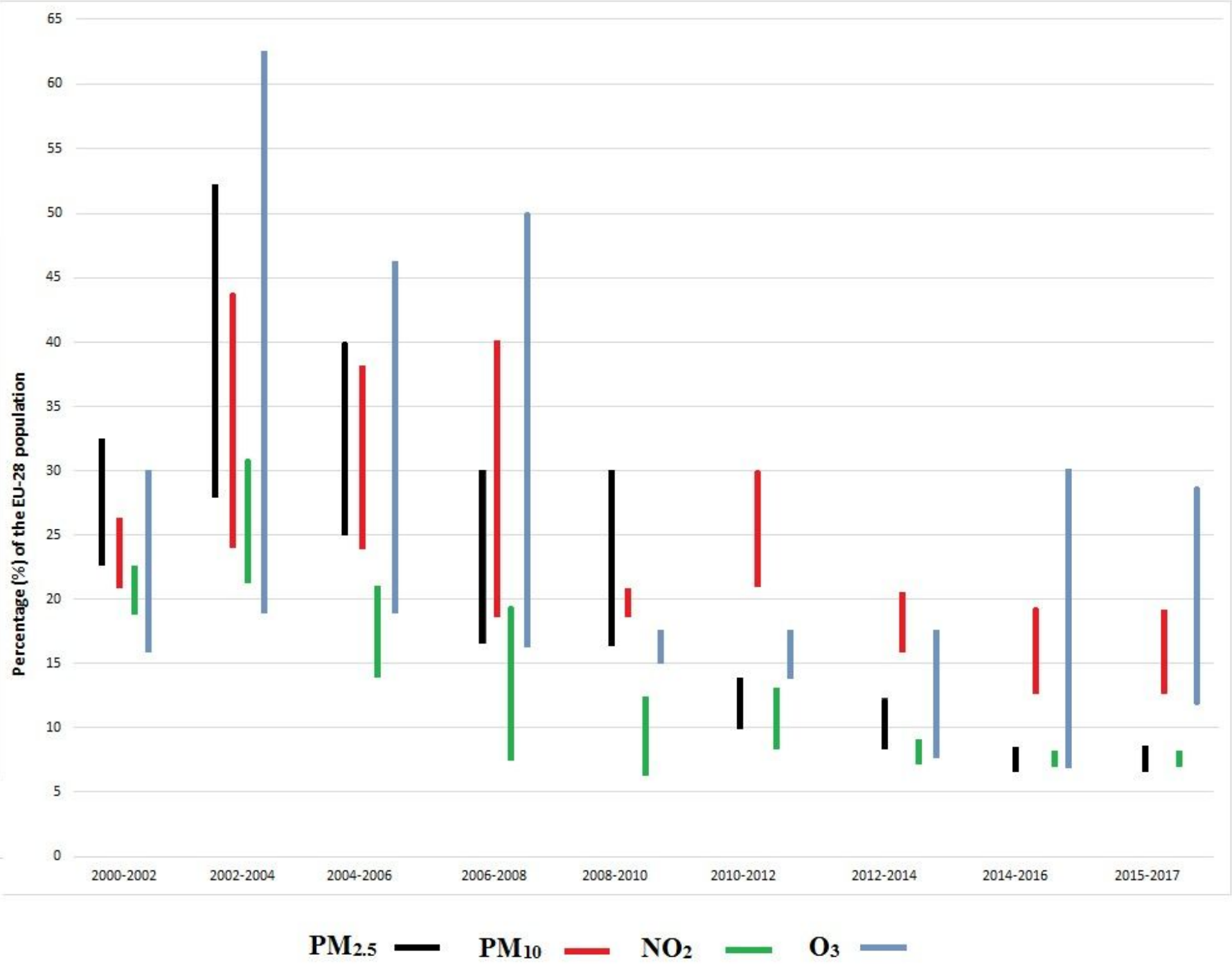

Figure 1

Minimum and maximum percentage of EU-28 population (in \%) exposed to air pollutants concentrations exceeding the European Union limit or target values between 2000 and 2017. 